\title{
HIGH PREVALENCE AND ASSOCIATION OF HIV-1 NON-B SUBTYPE WITH SPECIFIC SEXUAL TRANSMISSION RISK AMONG ANTIRETROVIRAL NAÏVE PATIENTS IN PORTO ALEGRE, RS, BRAZIL
}

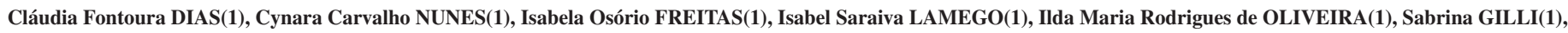
Rosângela RODRIGUES(2) \& Luis Fernando BRIGIDO(2)

\begin{abstract}
SUMMARY
In South Brazil the circulation of two HIV-1 subtypes with different characteristics represents an important scenario for the study of the impact of HIV-1 diversity on the evolution of the HIV-1 epidemic and AIDS disease. HIV-1 B, the predominant variant in industrialized countries and HIV-1 C, the most prevalent subtype in areas with rapid epidemic growth, are implicated in most infections. We evaluated blood samples from 128 antiretroviral (ARV) naïve patients recruited at entry to the largest HIV outpatient service in Porto Alegre. Based on partial pol region sequencing, HIV-1 C was observed in 29\%, HIV-1 B in $22.6 \%$ and, the recently identified CRF31_BC, in $23.4 \%$ of 128 volunteers. Other variants were HIV-1 F in $10 \%$ and other mosaics in 5.5\%. In order to evaluate the association of socio-behavioral characteristics and HIV-1 subtypes, interviews and laboratory evaluation were performed at entry. Our data suggest an established epidemic of the three major variants, without any evidence of partitioning in either of the subgroups analyzed. However, anal sex practices were associated with subtype B, which could indicate a greater transmissibility of non-B variants by vaginal intercourse. This study provides baseline information for epidemiologic surveillance of the changes of the molecular characteristics of HIV-1 epidemics in this region.
\end{abstract}

KEYWORDS: HIV-1 subtypes; HIV-1 CRF31_BC; Molecular epidemiology ; Risk factors; Brazil.

\section{INTRODUCTION}

It is estimated that over 33.2 million individuals are currently living with HIV/AIDS worldwide, 1.6 million in Latin America ${ }^{11}$. From 1980 to June 2007, 474,273 AIDS cases were identified in Brazil, 89,250 in the South region, with almost 43,388 in Rio Grande do Sul (RS)2.

A better knowledge of the genetic variability of the human immunodeficiency virus type I (HIV-1) can be crucial to the development of vaccine products and antiretroviral therapy. Worldwide, about 50\% of HIV infections are caused by HIV-1 subtype (clade) C, whereas subtype B predominates in industrialized countries, corresponding to about $10 \%$ of all infections. HIV-1 clade B is observed in all countries in the Americas, including Brazil. Although the predominance of clade $\mathrm{B}$ has been demonstrated in studies conducted in different regions of the country, non-B variants and recombinant forms are not uncommom ${ }^{5,7,14,24}$. On the other hand, clade $\mathrm{C}$ predominates in south Brazil ${ }^{4,6,17}$. Recently a near full length sequencing of a new recombinant form, CRF31_BC, has been reported ${ }^{19}$. The information about the number of people living with HIV-1 CRF31_BC is limited, especially among new, ARV naïve HIV infected patients. Moreover, the association between socio-behavioral factors and the infection caused by HIV major circulating variants has not been clearly established.
Our study aimed to evaluate the prevalence of the circulating recombinant form (CRF31_BC) in our population and to access the risk factors associated with the transmission of the major circulating variants among new, ARV naïve cases initiating follow up at our service, Serviço de Assistência Especializada em DST/AIDS, Prefeitura Municipal de Porto Alegre.

\section{MATERIALS AND METHODS}

This study was conducted at the Serviço de Assistência Especializada em DST/AIDS, the major unit dedicated to outpatient care of people with HIV/AIDS in Porto Alegre. The unit is part of the health system of the municipality of Porto Alegre (SAE/PMPA), the major metropolitan area in south Brazil. The service is located at Santa Tereza district, in the south of the city. By October 2008, about 8,000 patients with HIV/ AIDS, HTLV and/or STD had started a course of follow up treatment with the service. The majority of these patients live in the metropolitan area of Porto Alegre. Patients were invited to participate during the first visit to the clinic. After informed consent was signed, information on sociobehavioral factors, clinical and laboratorial status were obtained, along with additional blood samples for HIV sequencing. All patients signed the informed consent and agreed to participate in this initial evaluation and to be part of a prospective cohort. The recruitment spanned from July

(1) Serviço de Assistência Especializada em DST/AIDS da Prefeitura Municipal de Porto Alegre, Rio Grande do Sul, Brasil.

(2) Laboratório de Retrovirus, Instituto Adolfo Lutz, São Paulo, SP, Brasil.

Correspondence to: Cláudia Fontoura Dias, Rua Luiz de Camões 859/206, 90620-150 Porto Alegre, RS, Brasil. E-mail: cdias.voy@terra.com.br 


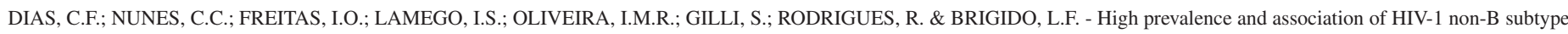
with specific sexual transmission risk among antiretroviral naïve patients in Porto Alegre, RS, Brazil. Rev. Inst. Med. trop. S. Paulo, 51(4): $191-196,2009$.

2004 to December 2005. The study was organized with the support of the Vaccine Initiative of the National AIDS Program, with the main objective being to implement a new HIV research site in the country. Due to the known co-circulation of different subtypes in the region, this initiative aimed to organize a small cohort in which physicians could evaluate the impact of HIV diversity in clinical evolution and ARV response. Two hundred and fifty three patients from the local voluntary counseling and testing site (VTC) and local public health network started follow up with our service during this period. The inclusion criteria were: age greater than 18 years, no previous exposure to ARV treatment, residence in the metropolitan area of Porto Alegre. Pregnant women were excluded. From the 253 patients, 17 were kept in follow up but excluded from the cohort at the second visit due to documented or potential use of ARV. Out of the remaining 236 patients, HIV sequencing was obtained from a random sampling of 128 individuals. Information was obtained from an individual questionnaire and data was collected by a trained research assistant. Clinical and laboratory data were obtained from patients' clinical files. Blood samples were collected with EDTA (Becton- Dickinson, San Jose, CA, USA) and analyzed for TCD4 (Flow Cytometry, BectonDickinson, San Jose, CA, USA) and viral load quantification (bDNA, Bayer diagnostics, Germany) at the local municipal laboratory following manufacturers' recommendation. Additional plasma was also collected with EDTA, separated by centrifugation and preserved at $-70{ }^{\circ} \mathrm{C}$ until use. Biological material was transported in dry ice to Adolfo Lutz in São Paulo. Plasma was concentrated by centrifugation at 22,000 $\mathrm{x}$ g for 120 min at $4{ }^{\circ} \mathrm{C}$. Plasma HIV viral RNA was isolated using Trizol reagent (GIBCO-USA) or Qiamp® viral RNA mini kit (Quiagen, Germany) according to manufactures' instructions. Complementary DNA synthesis was performed SuperScript III enzyme, (Life Technologies, USA) in a final volume of $20 \mu \mathrm{L}$, at $50{ }^{\circ} \mathrm{C}$ for $60 \mathrm{~min}$. HIV-1 polymerase fragment spanning the entire protease gene (PR) and part of reverse trancriptase (RT, codons 1 to 235, relative to HXB2) were obtained by PCR as previously described ${ }^{3}$. Purified products were sequenced in an automated ABI 3100 Genetic Analyser (Applied Biosystems, USA). All sequencing chromatograms obtained were assembled with Sequencher 4.7 software and manually edited to identify mixtures. Automatic assembly (http:// www.ial.sp.gov.br/cgi-bin/HIV/submissao/ submissao.pl) was used to verify quality and obtain contigs for phylogenetic analysis. HIV-1 clade was screened using both National Center for Biotechnology Information - NCBI (www.ncbi.gov) and REGA HIV-1 Subtyping Tool (http://jose. med.kuleuven.be) and further characterized by phylogenetic analysis as described below. Multiple alignments were performed using ClustalW multiple-sequence alignment software, with a reference set from the Los Alamos HIV-1 database (www.hiv.lanl.gov). Sequences were manually edited according to their codon-reading frame using BioEdit software. Neighbor Joining (NJ) and Maximum Likelihood (ML) trees were constructed based on appropriate nucleotide substitution models determined by Modeltest v3.7, tested with a hierarchical likelihood ratio test estimated under the HKY model, using PAUP (v4b10). Bootstrapping was performed using the stepwise addition algorithm for 1,000 replicates. Trees were visualized using the Tree View program. Sequences showing discordant PR/RT classification or outlier behavior on NJ trees or any non-B signal at the NCBI site (http://www.ncbi.nlm.nih.gov/projects/ genotyping/formpage.cgi) were selected for bootscanning analysis using SIMPLOT 2.5 to evaluate recombination breakpoints using HIV-1 Consensus sequences. Breakpoints suggested at the bootscanning plot allowed the delimitation of fragments that were subjected to jump cluster analysis. NJ trees were constructed with fragments of the alignments to see if the query sequence jumps to the subtype cluster observed in the bootscanning plot. Further investigations on breakpoint positions were made by inspection of subtype nucleotide signatures. The clinical and behavioral data were organized with Epidata. Data were exported and final analysis was performed with the SPSS version 14.0 program. Categorical variables were initially described with absolute and relative frequencies. Quantitative variables were explored by mean and standard deviation when symmetrical (normal distribution) and with median and interquartil distribution whenever asymmetric. Categorical variables were analyzed using Qui-square or Exact Fisher tests and quantitative variables were compared among groups using Analysis of Variance (ANOVA) or Kruskal Wallis test whenever the distribution were asymmetric.

The assumed level of significance was $5 \%$. The study was revised and approved by the Ethics Committee of the Health Secretary of Porto Alegre and of the Adolfo Lutz Institute. All patients signed informed consent when entering the study. The study was also approved by the National Ethics Committee (CONEP registry 9553, number 270/2004). The study was partially supported by the AIDS National Program (CFA 029/4 914BRA 3014 DST-AIDS II) and by the Municipal Health Department of Porto Alegre.

\section{RESULTS}

The majority of the patients were adults at productive age, referring to themselves as white (European) ethnic background. Serologic diagnosis of HIV infection dated from January 1992 to July 2005, but, in most cases $(74.2 \%)$ the diagnosis was made in 2004 or 2005 . The male/female ratio was 1.3:1. Sexual exposure, as the unique risk factor for acquisition of HIV, was reported by most individuals (94.5\%), with $87 \%$ of them reporting only heterosexual exposure. Exclusive vaginal intercourse was reported by $(54.5 \%)$ and $40.8 \%$ of the individuals reported anal sex.

HIV-1 subtype $\mathrm{C}$ was observed in $29 \%$ of the individuals, subtype $\mathrm{B}$ in $22.6 \%, \mathrm{CRF} 31 \_\mathrm{BC}$ in $23.4 \%$, $\mathrm{F}$ in $10 \%$ and other mosaics in $5.5 \%$. Molecular evaluation of these mosaics structures was described elsewhere ${ }^{3}$.

Of the 24 individuals infected with HIV-1 B, 16 (66.7\%) made reference to anal sex, 12 of these being male patients. Among the 28 individuals infected with CRF31_BC, 14 were male and 14 were female. Twenty one of the individuals (75\%) referred only to vaginal intercourse (with or without oral) practices. The occurrence of anal sex is significantly different when individuals infected with clade B are compared to CRF31_ $\mathrm{BC}(p=0.01)$ and overall, the practice of anal sex was more common among individuals infected with clade $\mathrm{B}$ as compared to non-B (C or CRF31_BC) $(p<0.013)$. Among women, 28\% mentioned the practice of anal sex. Exclusive vaginal/oral sex was referred to by most women infected with CRF31_BC (92.9\%; 13 out of 14), whereas anal sex was reported in $50 \%$ ( $4 / 8$ cases) of females infected with subtype B $(p<0.04)$.

Thirty five percent of the patients reported previous sexual exposure with a known HIV infected partner, $19.4 \%$ with an IDU partner, $12.6 \%$ with a male partner who had had sex with other men, $22.3 \%$ with sex workers and $25.2 \%$ with unknown partners. The consistent use of male condoms in all sexual intercourse was reported by $9.9 \%, 43.2 \%$ reported occasional use and $44.1 \%$ had never used condoms. Among the $68 \%$ of individuals that agreed to address drug relate issues, $11.5 \%$ 


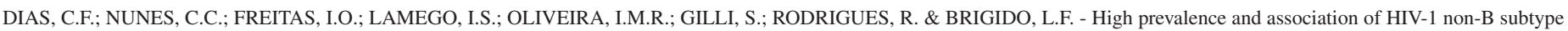
with specific sexual transmission risk among antiretroviral naïve patients in Porto Alegre, RS, Brazil. Rev. Inst. Med. trop. S. Paulo, 51(4): 191-196, 2009.

reported use of crack, $3.4 \%$ inhaled cocaine, $65.5 \%$ alcohol and $16.1 \%$ marijuana, with no differences among the HIV subtypes. Almost all individuals presented asymptomatic at first visit. The median CD4 count at enrollment was 330.5 cells $/ \mathrm{mm}^{3}$. No association with gender, ethnicity, sexual orientation, type of exposition, income, type of illicit drug, plasma viremia or TCD4 count at entry was observed. Table 1 summarizes the socio-behavioral factors, laboratory and clinical stage

Table 1

Social behavioral characteristics of the population $(\mathrm{n}=128) * *$

\begin{tabular}{|c|c|c|}
\hline & $\mathrm{N}$ & $\%$ \\
\hline AGE (mean) & 35.5 & \\
\hline \multicolumn{3}{|l|}{ Gender } \\
\hline Male & 72 & 56.3 \\
\hline Female & 56 & 43.8 \\
\hline \multicolumn{3}{|l|}{ Race } \\
\hline White & 76 & 59.4 \\
\hline Black & 36 & 28.1 \\
\hline Colored & 15 & 11.7 \\
\hline Other & 1 & 0.8 \\
\hline \multicolumn{3}{|l|}{ Sexual orientation* } \\
\hline Heterossexual & 107 & 87 \\
\hline Homossexual & 9 & 7.3 \\
\hline Bissexual & 7 & 5.7 \\
\hline \multicolumn{3}{|l|}{ Type of exposure } \\
\hline Sexual transmission & 121 & 94.5 \\
\hline Intravenous drug use & 17 & 14 \\
\hline \multicolumn{3}{|l|}{ Years of formal study } \\
\hline None & 8 & 6.3 \\
\hline From 1 to 3 years & 23 & 18 \\
\hline 4 to 7 & 39 & 30.5 \\
\hline 8 to 11 & 46 & 35.9 \\
\hline$>12$ years & 12 & 9.4 \\
\hline \multicolumn{3}{|l|}{ Monthly income* } \\
\hline No income & 17 & 14 \\
\hline $\mathrm{Up}$ to $\mathrm{U} \$ 350$ & 24 & 19.8 \\
\hline U\$ 350 - U\$ 1,000 & 36 & 29.8 \\
\hline Over U\$ 1,000 & 44 & 36.4 \\
\hline \multicolumn{3}{|l|}{ WHO* } \\
\hline I & 88 & 72.7 \\
\hline II & 17 & 14 \\
\hline III & 12 & 9.9 \\
\hline IV & 4 & 3.3 \\
\hline CD4 at entry & $330.5(130.5 ; 462.25)$ & \\
\hline CV INITIAL & $\begin{array}{l}16.628 .5(3264.75 ; 52.294 .75) \\
4.21(3.51 ; 4.7)\end{array}$ & \\
\hline
\end{tabular}

$\overline{\text { Table } 1 \text { depicts socio-behavioral, laboratory and clinical data from studied }}$ volunteers.

*Variables with missing data: income $\mathrm{n}=121$, sexual orientation $=123, \mathrm{WHO} \mathrm{n}=$ 121 ; **Data is presented by total (percentage), CD4 initial - median, (interquartil interval), $\mathrm{CV}$ initial - median (interquartil interval); $\log$ mean \pm standard deviation.
(WHO classification) of this population $(n=128)$. Table 2 describes viral subtypes or mosaics isolated from the blood samples of the participants. Table 3 shows sexual practices according to HIV-1 subtypes. Table 4 describes the different aspects evaluated according to HIV subtyping assignment. More detailed molecular characterization of these samples was recently published ${ }^{3}$. Sequences used in this work are available at Genbank, accession numbers: EF 379156-71; EF 393720-22; EF 39372551; EF 393759-810; EF 393846-48; EF 393851-75; EF 393892-940.

\section{DISCUSSION}

South Brazil had, in 2006, an incidence of 17 AIDS cases/100,000 inhabitants, with 21.2 in RS State ${ }^{2}$. At the municipality, with 1,420,667 inhabitants ${ }^{10}$, there was an AIDS prevalence rate of 76/100,000 in 2006, somewhat higher than that observed in 2005, (75.1 cases per 100,000

Table 2

HIV-1 clade at pol $(\mathrm{n}=128)$

\begin{tabular}{lcc}
\hline Viral clade at pol & N & $\%$ \\
\hline C & 37 & 29 \\
CRF31_BC & 30 & 23.4 \\
B & 29 & 22.6 \\
F & 13 & 10.1 \\
B_* & 7 & 5.5 \\
C_* & 5 & 3.9 \\
BC mosaics** & 3 & 2.3 \\
BF mosaics & 2 & 1.6 \\
CF mosaics & 2 & 1.6 \\
\hline TOTAL & 128 & 100 \\
\hline
\end{tabular}

Table 2 describes viral subtypes or mosaics isolated from study participants. *Samples with sequence from only protease or RT region; **All other BC mosaics with recombinant structure distinct from CRF31_BC.

Table 3

Sexual practice and HIV-1 subtype

\begin{tabular}{lcccc}
\hline & \multicolumn{2}{c}{$\begin{array}{c}\text { Vaginal (+/- oral) } \\
\text { exclusive n }(\%)\end{array}$} & Anal & $\mathrm{n}(\%)$ \\
& Males & Females & Males & Females \\
\hline HIV-1 B & $4(25)$ & $4(50)$ & $12(75)$ & $4(50)$ \\
HIV-1 C & $6(50)$ & $9(64.3)$ & $6(50)$ & $5(35.7)$ \\
CRF31_BC & $8(57.1)$ & $13(92.9)$ & $6(42.9)$ & $1(7.1)$ \\
\hline
\end{tabular}

Table 3 shows the absolute number (percentage) of cases relating either exclusive vaginal sexual intercourse (with or without oral sex) or those relating also anal sex according to gender, by HIV-1 subtype.

Practice of anal sex was more common among individuals infected with clade $\mathrm{B}$ as compared to non-B (C or CRF31_BC) $(p<0.013)$. The occurrence of anal sex is significantly different when individuals infected with clade $\mathrm{B}$ are compared to CRF31_BC $(p=0.01)$. Among women, exclusive vaginal/oral sex is significantly more common among females infected with CRF31_BC as compared to females infected with HIV-1 B $(p<0.04)$. 
DIAS, C.F.; NUNES, C.C.; FREITAS, I.O.; LAMEGO, I.S.; OLIVEIRA, I.M.R.; GILLI, S.; RODRIGUES, R. \& BRIGIDO, L.F. - High prevalence and association of HIV-1 non-B subtype with specific sexual transmission risk among antiretroviral naïve patients in Porto Alegre, RS, Brazil. Rev. Inst. Med. trop. S. Paulo, 51(4): 191-196, 2009.

Table 4

Patient characteristics according to clade (B, C and CRF31_BC)

\begin{tabular}{|c|c|c|c|c|}
\hline Characteristics & $\begin{array}{c}\mathrm{B} \\
\mathrm{n}=29(\%)\end{array}$ & $\begin{array}{c}\mathrm{C} \\
\mathrm{n}=37(\%)\end{array}$ & $\begin{array}{c}\text { CRF31_BC } \\
\mathrm{n}=30(\%)\end{array}$ & $p$ \\
\hline Male gender & $20(69)$ & $20(54.1)$ & $16(53.3)$ & 0.380 \\
\hline \multicolumn{5}{|l|}{ Race* } \\
\hline White & $19(65.5)$ & $17(45.9)$ & $18(62.1)$ & 0.53 \\
\hline Black & $7(24.1)$ & $14(37.8)$ & $8(27.6)$ & 0.553 \\
\hline Colored & $3(10.3)$ & $6(16.2)$ & $3(10.3)$ & 0.553 \\
\hline \multicolumn{5}{|l|}{ Sexual behavior* } \\
\hline Heterossexual & $21(75)$ & $29(87.9)$ & $27(90.0)$ & 0.356 \\
\hline Homossexual & $5(17.9)$ & $2(6.1)$ & $1(3.3)$ & 0.356 \\
\hline Bissexual & $2(7.1)$ & $2(6.1)$ & $2(6.7)$ & 0.356 \\
\hline \multicolumn{5}{|l|}{ Risk factor } \\
\hline Sexual & $28(96.5)$ & $32(86.4)$ & $30(100)$ & 1.0 \\
\hline UDI & $3(10.7)$ & $7(2.9)$ & $2(6.7)$ & 0.188 \\
\hline \multicolumn{5}{|l|}{ Monthly income* } \\
\hline Up to U\$ 350 & $8(30.8)$ & $12(35.3)$ & $13(43.3)$ & 0.144 \\
\hline U\$350 to - U\$1,000 & $4(15.4)$ & $13(38.2)$ & $9(26.5)$ & 0.144 \\
\hline Over U\$ 1,000 & $13(43.3)$ & $7(23.3)$ & $10(33.3)$ & 0.144 \\
\hline \multicolumn{5}{|l|}{ Type of drugs* } \\
\hline Alcohol & $14(66.7)$ & $13(56.5)$ & $15(75)$ & 0.442 \\
\hline Cocaine & 0 & 0 & $1(5)$ & 0.327 \\
\hline Crack & 0 & $3(13.0)$ & $5(25)$ & 0.053 \\
\hline IV & 0 & $3(13)$ & $2(10)$ & 0.248 \\
\hline Marijuana & $2(9.55)$ & $6(26.1)$ & $2(10)$ & 0.225 \\
\hline Initial CD4 & 282 & 274 & 271 & 0.873 \\
\hline Initial CV & $23.624(4.31)$ & $12.648(4.04)$ & $19.467(4.2)$ & 0.230 \\
\hline
\end{tabular}

Table 4 describes socio-behavioral, clinical and laboratory data by HIV-1 subtype isolated from study participants.

*Variables with missing data: race $\mathrm{n}=95$, sexual behavior $\mathrm{n}=91$, Monthly income $\mathrm{n}=89$, type of drug (only among users); **Data is presented by total (percentage), CD4 initial - median, (interquartil interval), CV initial - median (interquartil interval); log mean \pm standard deviation.

inhabitants) ${ }^{22}$. From 1983 to 2006, 15,301 cases were reported in Porto Alegre, a cumulative prevalence of 587 cases/100,000 inhabitants. No major changes in the risk factor profile of the epidemic have been observed in the last decade, with a predominance of heterosexual behavior (60.4\%), followed by intravenous drug usage (IDU) (16.1\%) and homo/ bisexual $(13 \%)$ behavior. IDU is considered a major factor in HIV dissemination and the city has the highest proportion of IDU related cases in the country ${ }^{22}$. The influence of these factors are expected to change with the evolution of the epidemic over time, and, as has been observed in other areas of Brazil, our newly identified HIV infected patients report a predominance of heterosexual behavior with low frequency of IDU related cases. Another aspect related to the current AIDS data is the increasing proportion of cases among women. In Brazil the male/ female ratio is changing, from 15:1 in 1986 to $1.5: 1$ in $2005^{2}$. Our study shows a higher proportion of females among these new cases. Regarding the risk factors for HIV acquisition, throughout the period of 1980 to 2007, a tendency has been observed towards the increasing proportion of heterosexual exposure, stabilization among homo/bisexuals and the reduction of UDI. Molecular characteristics have been associated with differences in epidemic potential, and in regions where HIV-1 $\mathrm{C}$ dominates, as in the countries in the south of Africa, the epidemic has grown at rates greater than that observed in areas dominated by other HIV variants 9 . If we take into account that the recombinant form CRF31_BC is made up of an almost entire $\mathrm{C}$ genome, with a small portion of clade B genome in the RT region, and the sum of clades C (29\%) and the CRF31_BC (23.4\%) at the analyzed polymerase region, HIV-1 C genomes constitute the majority of the infections in our cohort. This has been documented in other areas of the south of Brazil, especially in cities that report the highest incidence of AIDS cases in our country ${ }^{3}$. The fact that the CRF31_BC has been detected in such a large proportion in our 


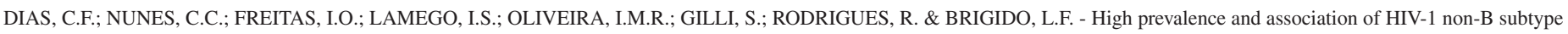
with specific sexual transmission risk among antiretroviral naïve patients in Porto Alegre, RS, Brazil. Rev. Inst. Med. trop. S. Paulo, 51(4): 191-196, 2009.

study and, albeit at a lesser proportion, also in other studies in the south of Brazil $^{3,17,19}$ may suggest some evolutionary advantage for this variant that needs to be investigated. The presence of clade $\mathrm{C}$ genome in Brazil was first documented in Porto Alegre, at a multicentric WHO study in $1992^{8}$. Earlier this decade, an important proportion of clade $\mathrm{C}$ was observed in Rio Grande city, to the south of our state ${ }^{13}$. In 2003 a prevalence of $45 \%$ of HIV-1 C among patients from the VTS at our public health unit was documented, but at the time no discrimination of CRF31_BC and clade C was performed ${ }^{4}$. Although the studies are independent, they may provide some insight into the potential growth of clade C in our area. In 2005, in another study in the city of Rio Grande, 85 patients were evaluated, mostly ARV experimented showing $45 \%$ of samples to be clade C, $42 \%$ clade $\mathrm{B}, 5 \% \mathrm{~F}$ and $6 \%$ recombinants ${ }^{23}$. In another study, conducted in the same year, 108 patients from our VTS showed a prevalence of $\mathrm{C}$ genome in 58\% of cases, with almost half (43\%) with the CRF31_BC breakpoint pattern at $\mathrm{RT}^{17}$. The presence of such a large proportion of samples with a similar breakpoint provided preliminary evidence for a potential new CRF. Re-analysis of samples previously registered at NCBI as near full length clade $\mathrm{C}$ where recognized to actually bear this breakpoint pattern at RT. The sequencing of new partial RT along with these reclassified near complete genome provides sufficient criteria for the identification of a new circulating recombinant form (CRF), numbered 31. Although identified in other services in the state and in the neighboring state of Santa Catarina ${ }^{3}$, the proportion observed in our service has never been documented elsewhere. This may suggest that the variant originated in communities served by our clinical unit. Previous attempts to evaluate the putative differential distribution of HIV variants in Brazil have evaluated experienced patients ${ }^{20}$. Our study is the first to evaluate exclusively naïve volunteers with HIV in the area, in a public service that harbors a similar proportion of individuals with C, B and CRF31_BC HIV variants. By removing the bias of treatment impact one may better probe distinctions in the populations infected with these variants. Moreover, detailed socio behavioral data, including information on certain sexual practices like anal sex were evaluated. Although clinical impact may only be assessed prospectively, clinical stage at entry may provide some preliminary information. At admission, $72.7 \%$ were asymptomatic. The median CD4 count at enrollment was 330.5 cells $/ \mathrm{mm}^{3}$. It is noteworthy that this degree of immune suppression is moderate compared to the other services in the country and even to some services in industrialized countries ${ }^{12}$. When we compare the median CD4 at entry among the distinct variants, our patients show comparable counts. The eventual distinct CD4 loss trend can only be evaluated with follow up determinations that may also clarify potential distinction on the rate of CD4 recovery after HAART. Follow up data from this cohort may provide information on clinical outcome and possible differential pathogenic potential across different variants.

The association of risk factors and HIV variants may help to explain the dynamics of the epidemic and identify eventual preferential modes of transmission of HIV variants ${ }^{21}$. In 2005, HAART experimented patients at another service in Porto Alegre were evaluated and no associations were observed, albeit that HIV-1 C was more frequent among women ${ }^{23}$. Our study does not confirm these findings, and the proportion of clade $\mathrm{C}$ among women is only marginally higher. This fact may be related to the higher proportion of clade B among gay men, and may be the reason why we found a greater proportion of anal sex among clade $B$ infected individuals. In fact, other studies suggest a preponderance of clade B among men that have sex with men $^{21}$. It is expected that the spread of HIV may benefit from the connectivity within vulnerable groups. This might be the case for the gay communities in our area with communities in Rio and São Paulo, were clade B predominates ${ }^{4}$. This could be a factor for the dissemination of this HIV subtype among these groups $^{1,16}$. Overall, our socio-behavioral data suggest that the three major variants (B, C and CRF31_BC) have similar distribution, without any sign of partitioning variants to a particular subpopulation. However, it is noteworthy that non-B clade, especially CRF31_BC, is associated with exclusive vaginal sex practices. The proportion of females reporting anal sex $(28 \%)$ is similar to that observed in US, were $29.6 \%$ of females aged 20-24 years report anal sex ${ }^{15}$. It is known that anal sex represents a higher risk of HIV acquisition ${ }^{18}$. Although the preponderance of subtype B among males could be ascribed to its preponderance in the Brazilian gay community, our data show a significant association of subtype B and anal sex even when only women are analyzed. It is tempting to associate non-B clades (subtype C or CRF31_BC) circulating in our area with an easier transmission potential, which would accordingly reflect a lesser dependence on the more risky anal transmission. This has been suggested in other settings but is still an open issue. Our sample size is small and further studies are necessary to confirm this hypothesis. Our study provides, however, baseline information that may allow the delineation of trends of the epidemic in coming years. Continuous surveillance is recommended to allow the monitoring of the eventual growth of some of these variants in the epidemic. This may be crucial for intervention measures and planning of public policies. Determining the eventual growth and dominance of clade $\mathrm{C}$ may not only help us understand the epidemic's dynamics, but may also contribute to the clarification of differences in the pathogenic and transmission potential of HIV subtypes, subsidizing vaccines and other innovations in HIV prevention and providing pivotal information for the epidemic's control.

\section{RESUMO}

\section{Alta prevalência e associação do subtipo não-B do vírus HIV-1 com risco específico de transmissão sexual entre pacientes virgens de tratamento antirretroviral em Porto Alegre, Brasil}

No sul do Brasil a circulação de dois subtipos de HIV-1 com características diferentes representa importante cenário para o estudo do impacto da diversidade do HIV-1 na evolução da epidemia e na AIDS. O HIV-1 B, variante predominante nos países industrializados e o HIV-1 C, o subtipo mais prevalente em áreas com maiores taxas de crescimento da epidemia, estão implicados na maioria das infecções. Avaliamos amostras de sangue de 128 pacientes sem exposição a antirretrovirais, recrutados ao ingressarem no maior serviço ambulatorial de HIV/AIDS de Porto Alegre. Com base no sequenciamento parcial da região pol, o HIV-1 C foi observado em 29\%, HIV-1 B em 22,6\% e uma forma recombinante recentemente descrita, CRF31_BC, foi observada em 23,4\% entre 128 voluntários. Outras variantes encontradas foram HIV-1 F em $10 \%$ e outros mosaicos em 5,5\%. Para avaliar associações entre características sócio-comportamentais e subtipos do HIV-1 foram realizadas entrevistas e exames laboratoriais na entrada do estudo. Nossos dados sugerem uma epidemia estabelecida dessas três variantes principais, sem evidência de compartilhamento em nenhum subgrupo analisado. Entretanto, prática sexual anal se mostrou associada à transmissão de subtipo $\mathrm{B}$, o que pode indicar maior transmissibilidade das variantes não-B por intercurso vaginal. Este estudo permite delinear uma linha de base para o monitoramento epidemiológico das mudanças nas características moleculares da epidemia do HIV-1 nesta região. 
DIAS, C.F.; NUNES, C.C.; FREITAS, I.O.; LAMEGO, I.S.; OLIVEIRA, I.M.R.; GILLI, S.; RODRIGUES, R. \& BRIGIDO, L.F. - High prevalence and association of HIV-1 non-B subtype with specific sexual transmission risk among antiretroviral naïve patients in Porto Alegre, RS, Brazil. Rev. Inst. Med. trop. S. Paulo, 51(4): 191-196, 2009.

\section{ACKNOWLEDGMENTS}

The authors gratefully acknowledge the contribution of study volunteers, our colleagues at the Central Laboratory of CSVC, the multidisciplinary group of SAE, in particular Cledimar Veiga and Gisele Preussler, the AIDS municipal coordinators, our colleagues from the research Capacitating Program (RCP), Ivaldo Olimpo and the Instituto Adolfo Lutz-SP laboratory group.

\section{REFERENCES}

1. AVILA, M.M.; PANDO, M.A.; CARRION, G. et al. - Two HIV-1 epidemics in Argentina: different genetic subtypes associated with different risk groups. J. acquir. immune Defic. Syndr., 29: 422-426, 2002.

2. BRASIL. MINISTÉRIO DA SAÚDE - Bol. Epidem. AIDS, 4(1), jul.-dez. 2006/jan.-jun. 2007.

3. BRÍGIDO, L.F.M.; NUNES, C.C.; OLIVEIRA, C.M. et al. - HIV type 1 subtype C and $\mathrm{CB}$ Pol recombinants prevail at the cities with the highest AIDS prevalence rate in Brazil. AIDS Res. hum. Retroviruses, 23: 1579-1585, 2007.

4. BRINDEIRO, R.M.; DIAZ, R.S.; SABINO, E.C. et al. - Brazilian network for HIV drug resistance surveillance (HIV-BresNet): a survey of chronically infected individuals. AIDS, 17: 1063-1069, 2003.

5. CABRAL, V.P.; CUNHA, C.B.; MAGALHÃES, E.F.L. et al. - Human immunodeficiency virus type-1 subtypes of infected patients in Espírito Santo, Brazil. Mem. Inst. Oswaldo Cruz, 101: 881-885, 2006.

6. CSILlAG, C. - HIV-1 subtype C in Brazil. Lancet, 344(8933): 1354, 1994.

7. GADELHA, S.R.; SHINDO, N.; CRUZ, J.N.M.; MORGADO, M.G. \& GALVÃOCASTRO, B. - Molecular epidemiology of human immunodeficiency virus- 1 in the State of Ceará, Northeast, Brazil. Mem. Inst. Oswaldo Cruz, 98: 461-463, 2003.

8. GAO, F.; YUE, L.; CRAIG, S. et al. - Genetic variation of HIV type 1 in four World Health Organization-sponsored vaccine evaluation sites: generation of functional envelope (glycoprotein 160) clones representative of sequence subtypes A,B,C and E. WHO Network for HIV Isolation and Characterization. AIDS Res. hum. Retroviruses, 10: 1359-1368, 1994.

9. HEMELAAR, J.; GOUWS, E.; GHYS, P.D. \& OSMANOV, S. - Global and regional distribution of HIV-1 genetic subtypes and recombinants in 2004. AIDS, 20(16): W13-W23, 2006.

10. INSTITUTO BRASILEIRO DE GEOGRAFIA E ESTATÍSTICA - SIDRA. População residente: Porto Alegre. Brasília, IBGE, 2007.

11. JOINT UNITED NATIONS PROGRAMME ON HIV/AIDS \& WORLD HEALTH ORGANIZATION - Global estimates for adults and children, 2007. Geneva, UNAIDS, 2007.
12. KERULY, J.C. \& MOORE, R.D. - Immune status at presentation to care did not improve among antiretroviral-naïve persons from 1990-2006. Clin. infect. Dis., 45: 1369-1374, 2007.

13. MARTÍNEZ, A.M.; BARBOSA, E.F.; FERREIRA, P.C. et al. - Molecular epidemiology of HIV-1 in Rio Grande, RS, Brazil. Rev. Soc. bras. Med. trop., 35: 471-476, 2002.

14. MORGADO, M.G.; GUIMARÃES, M.L.; GRIPP, C.B.W.G. et al. - Molecular epidemiology of HIV-1 in Brazil: high prevalence of HIV-1 subtype B and identification of an HIV-1 subtype D infection in Rio de Janeiro City. Evandro Hospital AIDS Clinical Research Group. J. acquir. immune Defic. Syndr. hum. Retrovirol., 18: 488-494, 1998.

15. MOSHER, W.D.; CHANDRA, W.D. \& JONES, A.J. - Sexual behavior and selected health measures: men and women 15-44 years of age, United States, 2002. CDC Advance data for vital and health Statistics number 362, 2005. http://www.cdc.gov/nchs/data/ ad/ad362.pdf (accessed on January 9, 2009).

16. RIOS, M.; FERNANDEZ, J.; JARAMILLO, P. et al. - Molecular epidemiology of HIV type 1 in Chile: differential geographic and transmission route distribution of B and F subtypes. AIDS Res. hum. Retroviruses, 21: 835-840, 2005.

17. RODRIGUES, R.; SCHERER, L.C.; OLIVEIRA, C.M. et al. - Low prevalence of primary antiretroviral resistance mutations and predominance of HIV-1 clade $\mathrm{C}$ at polymerase gene in newly diagnosed individuals from South Brazil. Virus Res., 116: 201-207, 2006.

18. ROYCE, R.A.; SEÑA, A.; CATES Jr., W. \& COHEN, M.S. - Sexual transmission of HIV. New Engl. J. Med., 336: 1072-1078, 1997.

19. SANTOS, A.F.; SCHRAGO, C.G.; MARTINEZ, A.M.B. et al. - Epidemiologic and evolutionary trends of HIV-1 CRF31_BC - related strains in Southern Brazil. J. acquir. immune Defic. Syndr., 45: 328-333, 2007.

20. SANTOS, A.F.; SOUZA, T.M.; SOARES, E.A.J.M. et al. - Characterization of a new circulating recombinant form comprising HIV-1 subtypes C and B in Southern Brazil. AIDS, 20: 2011-2019, 2006.

21. SEGURA, M.; SOSA ESTANI, S.; MARONE, R. et al. - Buenos Aires cohort of men who have sex with men: prevalence, incidence, risk factors, and molecular genotyping of HIV type 1. AIDS Res. hum. Retroviruses, 23: 1322-1329, 2007.

22. SECRETARIA MUNICIPAL DE SAÚDE DE PORTO ALEGRE. EQUIPE DE VIGILÂNCIA DAS DOENÇAS TRANSMISSÍVEIS. COORDENADORIA GERAL DE VIGILÂNCIA EM SAÚDE - Aids. Epidemia em Porto Alegre. Bol. Epidem. AIDS, 9(34), agosto 2007.

23. SOARES, E.A.J.M.; MARTINEZ, A.M.B.; SOUZA, T.M. et al. - HIV-1 subtype C dissemination in Southern Brazil. AIDS, 19(suppl. 4): S81-S86, 2005.

24. VÉRAS, N.M.C.; VÉRAS, V.S.; RAMALHO, E.D. et al. - HIV type 1 genetic variability in Central Brazil. AIDS Res. hum. Retroviruses, 23: 1481-1490, 2007.

Received: 15 April 2009

Accepted: 24 July 2009 